\title{
Technical report: ethical and policy issues in genetic testing and screening of children
}

\author{
Laine Friedman Ross, MD, PhD ${ }^{1-2}$, Howard M. Saal, MD ${ }^{3}$, Karen L. David, MD, MS ${ }^{4,6}$ and \\ Rebecca R. Anderson, JD, MS5; and the American Academy of Pediatrics; \\ American College of Medical Genetics and Genomics
}

The genetic testing and genetic screening of children are commonplace. Decisions about whether to offer genetic testing and screening should be driven by the best interest of the child. The growing literature on the psychosocial and clinical effects of such testing and screening can help inform best practices. This technical report provides ethical justification and empirical data in support of the

\section{INTRODUCTION}

Two major events occurred in the 1950s that forever changed the influence of genetics in medicine: Watson and Crick ${ }^{1}$ described the double-helix model of DNA structure in 1953, and in 1956 Tjio and Levan ${ }^{2}$ established that the typical human carries 46 chromosomes. The goal of mapping and sequencing the human genome began in 1990, and a working draft was presented in 2000, with a more complete edition published in 2003. ${ }^{3}$ Knowledge of genetics and genomics continues to grow rapidly, as does consumer interest in genetic testing. As a result, statements about genetic testing and screening of children in the United States written in the past two decades need to be updated to consider the ethical issues that arise with the new technologies and expanded uses of genetic testing and screening. ${ }^{4,5}$ The growing literature on the psychosocial and clinical effects of genetic testing and screening can help inform us about best practices regarding diagnostic genetic testing, pharmacogenetics, newborn screening, carrier screening, testing asymptomatic children for genetic conditions that present later in childhood or adulthood, and how to respond to direct-toconsumer testing and the potential of genomic profiling.

Genetic testing and screening of minors are commonplace. "Genetic screening" denotes assays undertaken on a population-wide basis to identify at-risk individuals. "Genetic testing" denotes assays designed to provide a definitive diagnosis; these are performed because of positive screening results, family history, ethnicity, physical stigmata, or other reasons. Every year, approximately 4 million infants in the United States undergo newborn screening with state-chosen panels of rare metabolic, proposed policy recommendations regarding such practices in a myriad of settings.

Genet Med 2013:15(3):234-245

Key Words: carrier identification; disclosure; genetic screening; genetic testing; newborn screening; predictive testing

hematologic, and endocrine abnormalities for which early treatment may prevent or reduce morbidity or mortality. Most of the genetic conditions included in the state screening panels are autosomal recessive disorders, and some assays identify heterozygote carriers (e.g., hemoglobinopathies). Future screening may expand to X-linked conditions (e.g., Duchenne muscular dystrophy) and autosomal dominant conditions. In addition, universal newborn hearing screening allows for early identification of both acquired and hereditary hearing loss.

Outside of newborn screening, pediatric genetic testing is much less common. Diagnostic genetic testing may be performed on a child with physical, developmental, or behavioral features consistent with a potential genetic syndrome or for pharmacogenetic drug selection and dosing decisions. Predictive genetic testing may be performed on a child with a positive family history for a specific genetic condition, particularly if early surveillance or treatment may affect morbidity or mortality. Minors may also undergo histocompatibility testing as potential organ or tissue donors. This technical report provides ethical justification and empirical data in support of the recommendations enumerated in the accompanying policy statement. ${ }^{6}$ Genetic research (including the use and retention of dried blood spots and whole-genome sequencing) is beyond the scope of this technical report and accompanying policy statement.

\section{DIAGNOSTIC GENETIC TESTING}

When performed for diagnostic purposes in a child with symptoms of a genetic condition, genetic testing is similar to other medical diagnostic evaluations. Parents or guardians should

\footnotetext{
${ }^{1}$ Department of Pediatrics, University of Chicago, Chicago, Illinois, USA; ${ }^{2}$ Department of Medicine, MacLean Center for Clinical Medical Ethics, University of Chicago, Chicago, Illinois, USA; ${ }^{3}$ Division of Human Genetics, Cincinnati Children's Hospital Medical Center, Cincinnati, Ohio, USA; ${ }^{4}$ Department of Pediatrics, Metropolitan Hospital Center, New York, New York, USA; ${ }^{5}$ College of Public Health, University of Nebraska Medical Center, Omaha, Nebraska, USA; ${ }^{6}$ Department of Medicine, New York Methodist Hospital, Brooklyn, New York, USA. Correspondence: Laine Friedman Ross (lross@uchicago.edu) 
be informed about the potential benefits and potential harms of testing, and their permission should be obtained. Medical benefits include the possibility of preventive or therapeutic interventions, decisions about surveillance, the clarification of diagnosis and prognosis, and recurrence risks. Medical harms occur if parents or guardians respond to the results by pursuing unproven treatments or preventive measures, particularly if they are ineffective or have significant adverse effects (e.g., megadoses of vitamin A have been proposed for children with developmental disabilities but can cause liver toxicity). ${ }^{7}$ Discovery of misattributed parentage ${ }^{8}$ is a potential risk of certain genetic tests. Other "incidental" findings can be life saving (e.g., identifying a gene that predisposes to a preventable cancer) or psychologically disruptive (e.g., identifying a gene sequence variant of unknown clinical significance). If the medical benefits of a test are uncertain, will not be realized until a later time, or do not clearly outweigh the medical risks, the justification for testing is less compelling.

Pharmacogenetic testing to determine safety and efficacy of drugs is expanding. ${ }^{9}$ Currently, such testing is most commonly used in pediatrics for drug selection and dosing regulation in cancer therapies, ${ }^{10,11}$ psychiatric conditions, ${ }^{12-14}$ pain management, ${ }^{15-17}$ and asthma. ${ }^{18,19}$ The aim of pharmacogenomics is to improve therapeutic responsiveness and reduce the incidence of adverse drug reactions. ${ }^{20}$ If test results are expected to have clinical significance beyond drug selection and dosing (e.g., diagnostic or prognostic implications), then the additional implications of the genetic information should be disclosed before testing.

\section{NEWBORN SCREENING}

Virtually every infant in the United States has blood collected to screen for a variety of metabolic, endocrine, hematologic, and infectious conditions within the first week of life. Stateadministered newborn screening programs arose following Guthrie's development of an assay in 1961 to detect phenylketonuria using dried blood spots collected on filter paper. Initially, some professional groups opposed the rapid population-based implementation of this assay, citing the lack of longterm data on the dietary intervention and correctly predicting that a subset of children could be harmed by overtreatment. ${ }^{21}$ However, the devastating nature of phenylketonuria, its treatability, and the availability of an inexpensive assay made widescale population screening both feasible and acceptable.

As public health screening continued to expand, the World Health Organization commissioned a study by Wilson and Jungner ${ }^{22}$, who in 1968 enumerated 10 criteria "to guide the selection of conditions that would be suitable for screening." (Table 1). Although not written specifically for genetic applications, the criteria have served as a policy standard for population-based genetic screening over the past four decades. In recent years, some authorities have advocated minor ${ }^{23}$ or substantial ${ }^{24}$ modifications to the criteria in response to evolving technologies. Despite variability in how the criteria are interpreted, ${ }^{25}$ there is broad consensus that to qualify for populationbased screening, the natural history of a candidate condition
Table 1 Wilson and Jungner classic screening criteria

1. The condition sought should be an important health problem.

2. There should be an accepted treatment for patients with recognized disease.

3. Facilities for diagnosis and treatment should be available.

4. There should be a recognizable latent or early symptomatic stage.

5. There should be a suitable test or examination.

6. The test should be acceptable to the population.

7. The natural history of the condition, including development from latent to declared disease, should be adequately understood.

8. There should be an agreed policy on whom to treat as patients.

9. The cost of case finding (including diagnosis and treatment of patients diagnosed) should be economically balanced in relation to possible expenditure on medical care as a whole.

10. Case finding should be a continuing process and not a "once and for all" project.

Data from ref. 22

should be understood, an acceptable intervention for affected individuals should be available, and cost-effective screening and confirmatory testing should be available..$^{22-24}$

Debates about which conditions should be included in state newborn screening panels grew in importance as variations grew between states and advocacy groups began to express equity concerns. ${ }^{26}$ By the mid-1990s, some states were screening for more than 30 conditions, whereas others were screening for fewer than $5 .{ }^{27}$ In 2002, the American College of Medical Genetics and Genomics (ACMG) conducted a systematic evaluation of newborn screening programs, sponsored by the Maternal and Child Health Bureau of the Health Resources and Services Administration. Eighty-three conditions were assessed for possible inclusion in a uniform screening panel. ${ }^{28}$ After evaluating the empirical evidence for these conditions and gathering opinions from experts and advocacy constituents, the ACMG chose to consider candidate conditions within the context of multiplex platform technology, such as tandem mass spectrometry, which is capable of identifying many conditions simultaneously. Other professional groups had previously noted that multiplex testing was likely to reveal information about conditions that did not meet the Wilson and Jungner screening principles ${ }^{27}$. The ACMG evaluation also took into consideration the benefits of screening that may accrue to the family even if none accrued to the child being screened. Although family benefit as a justification for screening has been supported by one professional group statement, ${ }^{22}$ it has been rejected by others. ${ }^{4,5,27,29-34}$

The ACMG report recommended 29 primary targets for universal screening. It recognized 25 secondary conditions identifiable through multiplex testing on the core conditions, for which the natural history, the need for treatment, the duration of treatment, or the efficacy of treatment were insufficiently understood to recommend screening at the time of the report. Although many parent advocacy groups press for further expansion on the grounds that knowledge is beneficial to families, ${ }^{26}$ expanded screening carries potential harms. With every added condition, the frequency of false-positive results increases. ${ }^{35}$ Confirmatory 
testing is likely to avert unneeded medical interventions, ${ }^{36}$ but other possible adverse effects include psychosocial and emotional distress and the potential distortion of parental perceptions about the child. ${ }^{4,5,29,30,37-42}$ Similarly, expanded screening may also give rise to "patients in waiting": individuals with a genetic diagnosis who have no signs or symptoms and may remain asymptomatic for years or decades. ${ }^{41,42}$

The uniform panel proposed by the ACMG study was endorsed by the US Department of Health and Human Services Secretary's Advisory Committee on Heritable Disorders in Newborns and Children, and all states have adopted the panel despite some criticisms regarding its methodology. ${ }^{43,44}$ The Advisory Committee has since developed more stringent criteria for adding conditions to the uniform pane ${ }^{45}$ and in 2010 recommended the addition of severe combined immunodeficiency. ${ }^{46}$ Also needed is a process to delete conditions ultimately shown to be inappropriate for screening, ${ }^{47}$ although no conditions have been challenged, to date, in the United States.

The American Academy of Pediatrics (AAP) and ACMG support the mandatory offering of newborn screening for all children. Following education and counseling about the substantial benefits of newborn screening, its remote risks, and the next steps in the event of a positive screening result, parents should have the option of refusing the procedure, and an informed refusal should be respected.

A matter of ongoing debate is how best to involve parents in consent for newborn screening. ${ }^{27}$ Currently, most jurisdictions mandate newborn screening, with only Wyoming and the District of Columbia requiring active parental consent, although neither requires written consent. With the exception of Nebraska, all states allow parents to opt out, although they differ in what reasons parents may give for refusing. ${ }^{34}$ Given the number of conditions screened for, a consent process discussing each condition in detail is neither feasible nor desirable. Rather, studies consistently show that parents wish to be told why newborn screening is being performed, where they can obtain more information, and what they can expect in the event of an abnormal result. ${ }^{48-52}$ Studies show that most parents prefer to be informed about newborn screening during prenatal care, ${ }^{48,49,51,52}$ and a statement by the American College of Obstetricians and Gynecologists supports this practice. ${ }^{53}$ Research on informed consent increasingly supports a model of shared decision making, with emphasis on conversation rather than documentation. ${ }^{47-50,54}$

The principle of respect for autonomy is operationalized in the process of informed consent. When the individual lacks decisionmaking capacity, as all newborn infants do, the principle typically is expanded to include surrogate permission for medical interventions. ${ }^{5-57}$ Legal principles of privacy and self-determination support considerable deference to child-rearing decisions made by parents or guardians, with state intervention generally confined to instances of abuse or neglect. ${ }^{55-57}$ Although virtually all physicians would agree that the benefits of newborn screening far outweigh the risks and harms, few would assert that refusing screening constitutes medical neglect, given that the likelihood of a true-positive screening result is quite low. ${ }^{55-59}$ Obtaining parental permission may also increase the likelihood that a parent who receives notice of a positive screening result will be better prepared to respond appropriately and in a timely manner., ${ }^{4,27,49,50,54}$

Three main objections have been raised against requiring formal parental permission for newborn screening. One is that the benefits of early diagnosis and treatment so greatly outweigh the risks that the state is justified in requiring screening to preserve its own interest in healthy children. The second is that requiring parental permission will lead to a large number of refusals, leaving many children untested and at risk of having a condition undiagnosed. The third is that formal consent will be superficial and time consuming. Although studies have shown high acceptance rates even when formal parental permission is required, ${ }^{60}$ the argument that the benefits greatly outweigh the harms loses some of its force as newborn screening expands to include conditions for which early diagnosis does not necessarily reduce morbidity. ${ }^{61,62}$ This has been described by Grosse et al. ${ }^{63}$ as a shift in the criteria for newborn screening panels from identifying conditions that require immediate attention in order to avoid morbidity and mortality ("public health emergencies") to identifying conditions that do not require immediate therapy or for which therapy is not well established ("public health service"). The President's Bioethics Council argued that conditions should be divided into tiers to distinguish those with a high benefit-to-harm ratio from those that are more ambiguous, with greater parental discretion accorded as the benefit-to-harm ratio decreases. ${ }^{34}$

The recommendation of the AAP and the ACMG that parental permission be obtained for newborn screening does not specify how permission should be obtained or documented. ${ }^{64}$ Traditionally, written informed consent has not been required, ${ }^{4}$ although there is recent support for written documentation of refusal. ${ }^{52}$ Given the importance of newborn screening to reduce morbidity and mortality, all parents should be offered newborn screening and all parents must be educated about the process and its purpose. The optimal nature of the consent and refusal process may emerge from different states electing different processes if systematic data about the strengths and weaknesses of the different methods are collected.

\section{CARRIER SCREENING}

The AAP and the ACMG do not support routine carrier testing or screening for recessive conditions when carrier status has no medical relevance during minority. $4,5,27,29,30,65$ This recommendation accords with previous statements supporting the future decisional autonomy of the minor, who will be able to make an informed choice about testing once he or she reaches the age of majority. Possible harms of early testing include labeling, stigma or discrimination, and a potential for misunderstanding the distinction between carrier status and affected status. The history of sickle cell screening in the 1970s exemplifies the risk of harm when information is poorly or inaccurately conveyed. Physician and lay confusion about the meaning of test results led to employment and insurance discrimination, fear, and stigma, compromising not only the interests of tested 
individuals but also the credibility of the medical community and public health services. ${ }^{27,66,67}$

Possible benefits of carrier screening and disclosure in childhood include potentially greater acceptance and integration of status into life plans, avoidance of the shock and resentment that may accrue when disclosure is delayed, and greater opportunity for parental guidance in appreciating the nature of the genetic challenge and available management options. A recent review of empirical data regarding the effects of carrier testing on children concluded that "current research provides little evidence of a significant negative or positive impact on an array of indicators of psychosocial well-being". ${ }^{8}$ However, the authors acknowledged that "the methodological approaches used in quantitative studies might have been inadequate to detect important effects on children's emotions, self-perception, and social well-being". ${ }^{68}$

As noted previously, newborn screening may identify carriers for recessive conditions, such as hemoglobinopathies, galactosemia, and cystic fibrosis. There is broad consensus that when carriers are identified in newborn screening, carrier status should be disclosed to the child's parents or guardians. ${ }^{27}$ Disclosure is supported primarily by the argument that carrier status is information about the child that belongs to the child and the parents are the appropriate surrogates. ${ }^{27}$ Carrier information about the child also has implications for the parents and their own reproductive risks, which may be perceived as a benefit of disclosure.

The rationale against routine carrier screening of minors is altered when carrier status has potential medical implications during minority. For example, the National Collegiate Athletic Association now requires sickle cell trait screening of all Division I athletes, proof of prior testing, or a written waiver from the athlete before participation in its programs. The justification for this policy is that adolescents and young adults with sickle cell trait have been shown to be at increased risk of exercise-related splenic infarct or fatal exertional rhabdomyolysis. ${ }^{69}$ However, others argue against screening because risk can be prevented, or at least reduced, by modifying training for all athletes-a policy that would minimize morbidity and mortality without stigmatization. ${ }^{70,71}$ Carriers of other conditions have also been found to be at risk of health conditions, for example, $20-30 \%$ of female carriers of Duchenne muscular dystrophy develop cardiomyopathies ${ }^{72}$ and fragile $\mathrm{X}$ premutation carriers are at risk of primary ovarian insufficiency and fragile $\mathrm{X}$ tremor-ataxia syndrome. ${ }^{73}$ As more knowledge is gained about genetics and genetic conditions, it may be discovered that a continuum of expression is the norm rather than the exception, and the distinction between "carrier testing" and assessment for clinical purposes may diminish.

Carrier screening may also be appropriate for adolescents who are pregnant or considering reproduction. The legal authority for pregnant adolescents to make reproductive health-care decisions independent of their parents or guardians varies from state to state. Health-care providers should be aware of the regulations in their jurisdictions before proceeding with genetic assays in pregnancy during minority.
The AAP and the ACMG do not support school-based genetic screening or testing because the school setting raises concerns about whether the uptake is informed and voluntary, whether privacy and confidentiality are maintained, and whether appropriate genetic counseling is provided before and after testing. ${ }^{74}$

\section{PREDICTIVE GENETIC TESTING}

Predictive genetic testing can occur in many contexts and can refer to predictive testing of either a childhood-onset or adultonset condition, a distinction not made in previous statements about the genetic testing of children. ${ }^{75}$ It may involve testing an asymptomatic male infant with a positive family history for Duchenne muscular dystrophy or testing a child for a mutation associated with an adult-onset cancer syndrome. The former is an example of "predictive" testing: the presence of the mutation will almost certainly give rise to clinical manifestations. The latter is an example of "predispositional" testing: most (not all) cancer genes are incompletely penetrant and may never become manifest. Most predictive genetic testing for adult-onset conditions is predispositional.

Early professional statements recommended that predictive genetic testing of minors be considered only if effective medical interventions were available to treat, prevent, or retard the course of the disease. ${ }^{4,30}$ Since then, more than two dozen additional national and international guidelines have concurred. ${ }^{76}$ These statements identified a number of possible benefits and harms of predictive genetic testing for adult-onset conditions. ${ }^{4,30}$ Medical benefits include the possibility of evolving therapeutic interventions, targeted surveillance, refinement of prognosis, and clarification of diagnosis. Medical harms include misdiagnosis to the extent that genotype does not correlate with phenotype, ambiguous results in which a specific phenotype cannot be predicted (e.g., incompletely penetrant Huntington disease with 36-39 CAG repeats), and use of ineffective or harmful preventive or therapeutic interventions. Psychosocial benefits include reduction of uncertainty and anxiety, the opportunity for psychological adjustment, the ability to make realistic life plans, and sharing the information with family members. Psychological harms include alteration of self-image, distortion of parental perception of the child, increased anxiety and guilt, altered expectation by self and others, familial stress related to identification of other at-risk family members, difficulty obtaining life and/or disability insurance, and the detection of misattributed parentage. Reproductive benefits include avoiding the birth of a child with genetic disease or having time to prepare for the birth of a child with genetic disease. Reproductive harms include changing family-planning decisions on the basis of social pressures.

Although scant empirical data existed when earlier statements were written, the concern for harms was paramount, and the general consensus was to discourage if not proscribe predictive genetic testing of minors for late-onset conditions. In the intervening decades, some empirical data have emerged ${ }^{68}$ They suggest less harm than anticipated, with considerable resiliency and ability of minors to successfully incorporate these risks 
into their self-concepts and life plans. However, these studies disproportionately represent white individuals of higher socioeconomic status; the effects on lower educated and underserved populations are largely unknown. ${ }^{77}$

Data show that in hypothetical situations, adults express a high interest in genetic testing for cancer predisposition (8498\%); however, of those actually at risk, only half proceed with testing. ${ }^{78}$ Uptake of genetic testing is even lower for untreatable conditions, such as Huntington disease, with $<20 \%$ of at-risk individuals undergoing testing. ${ }^{79-82}$ Given the wide variation in preferences among adults, commentators argue that allowing parents or guardians to test their minor children unfairly preempts the future choices of those children. The AAP and the ACMG continue to support the traditional professional recommendation to defer genetic testing for late-onset conditions until adulthood. However, predictive genetic testing may be appropriate in limited circumstances. ${ }^{83}$ In deciding whether a child should undergo predictive genetic testing for late-onset conditions, the focus must be on the child's medical best interest; however, parents and guardians may also consider the potential psychosocial benefits and harms to the child and the extended family. ${ }^{84}$ Extending consideration beyond the child's medical best interest not only acknowledges the traditional deference given to parents about how they raise their children ${ }^{55-57}$ but also recognizes that the interest of a child is embedded in and dependent on the interests of the family unit. In some families, the psychosocial burden of ambiguity may be so great as to justify testing during childhood, particularly when parents and mature adolescents jointly express interest in proceeding. Some parents may seek predictive genetic testing for adult-onset conditions even when children are unable to participate in the decisionmaking process because of immaturity or cognitive impairment. After careful genetic counseling, it may be ethically acceptable to proceed with predictive genetic testing to resolve disabling parental anxiety or to support life-planning decisions that parents sincerely believe to be in the child's best interest. ${ }^{83,85}$

Thorough genetic counseling before predictive testing is essential to ensure that parents, guardians, and maturing minors fully understand the limits of genetic knowledge and treatment capabilities as well as the potential for psychological harm, stigmatization, and discrimination. ${ }^{65,85,86}$ Characterizing predictive genetic testing as an elective medical procedure helps to frame issues of consent. In general, an elective medical procedure is conditioned on the child's assent as well as parental permission. ${ }^{87}$ If an adolescent is not interested in testing, and the clinical benefits of knowing will not be relevant for years to decades, the adolescent's dissent should be final. If a minor is young or immature, delaying testing until the minor can actively participate shows respect for the developing capacities of the maturing minor.

Adolescents occasionally seek predictive genetic testing without parental involvement. Health-care providers should be cautious about providing such testing to minors without the collaboration of their parents. Results may disclose information about parental status, thus compromising parental privacy. In addition, data show that adults have difficulty understanding the full implications of genetic information, and they often involve other adults in their decision making. ${ }^{88-91}$ Permitting an adolescent to make similar choices without the benefit of parental guidance is problematic. It is also not clear by what authority minors would be able to avoid parental participation. Although some genetic testing may be relevant to pregnancy management for adolescents, predictive information about adult-onset conditions does not often enter into prenatal decision making. ${ }^{92,93}$ Predictive genetic testing does not typically affect management of emergency medical conditions. If clinical benefits will not accrue for years to decades, testing should be deferred until adulthood or should require parent or guardian permission as well as adolescent assent. ${ }^{87}$

In the case of predictive testing for childhood-onset conditions or conditions for which childhood interventions will ameliorate future harm, the balance of interest may be altered in favor of early testing (e.g., children at risk of familial adenomatous polyposis are tested before adolescence to determine whether annual colonoscopy should be initiated or if there is a risk of hepatoblastoma and a need to initiate ultrasonographic screening). In such cases, parental authority to determine medical treatment supersedes the minor's preferences with regard to liberty and privacy.

Significant deference should be extended to parents regarding the timing of predictive genetic testing for childhood-onset conditions. Parents may want this information early for lifeplanning purposes, such as choosing an appropriate dwelling in a community with appropriate services. Parents may also desire this information for reproductive planning, including the number and spacing of children, the use of assisted reproductive technology, or the use of prenatal diagnosis. Deferred testing is also acceptable as long as delayed diagnosis does not compromise the well-being of the child.

\section{HISTOCOMPATIBILITY TESTING}

The human leukocyte antigen (HLA) system comprises the major histocompatibility complex in humans. Genetic testing for HLA matching is most important for bone marrow and less important for solid organs. Because siblings have a $25 \%$ chance of being HLA identical, they are an important potential source of hematopoietic stem cells. HLA-matched siblings often are preferred as stem cell donors because of reduced risks of graft rejection, graft-versus-host disease, and other transplant-related complications compared with unrelated donors. Although HLA testing serves no clinical benefit for the child per se, the AAP and the ACMG believe that tissue compatibility testing of minors of all ages for stem cell donation for stem cell donation is permissible to benefit immediate family members. ${ }^{94}$ Such testing should be conducted only after thorough exploration of the psychosocial, emotional, and physical implications for the minor serving as a potential donor. ${ }^{84}$ Previous AAP statements support the participation of a donor advocate for all minors when tissue or, more rarely, when solid organ donation is contemplated. ${ }^{94,95}$ 
The role of HLA testing on embryos as part of preimplantation genetic diagnosis and in vitro fertilization goes beyond the scope of this technical report and accompanying policy statement.

\section{ADOPTION}

Some individuals planning adoption request preadoption genetic testing of the child. A joint policy statement of the American Society of Human Genetics and the ACMG issued in 2000 concluded that, in general, the same guidelines developed for children in biological families should apply for adopted children and children awaiting placement for adoption. ${ }^{96}$ However, a Working Party of the Clinical Genetics Society (United Kingdom) asked "whether there are particular considerations that might justify the genetic testing of a child being considered for adoption..." 30 The Working Party noted that, although most adoptive parents are involuntarily infertile, some seek adoption to avoid a particular heritable condition. Their personal experiences are likely to affect their views on genetic conditions in a prospective adoptive child ${ }^{30}$ and warrant closer consideration.

Clearly, prospective adoptive parents have an interest in obtaining as much family medical history as possible and should be informed of any clinical genetic concerns identified in a comprehensive physical and developmental examination. Whether prospective adoptive parents may undertake broader genetic investigation is more controversial. ${ }^{97-102}$ Admittedly, biological parents have substantial discretion in prenatal genetic testing, the results of which can inform decisions about postnatal management as well as pregnancy interruption. In the case of adoption, similar information may be requested to help an individual or couple decide whether they have the capacity and resources to raise a child with a specific known condition. However, testing may leave the child with a potentially stigmatizing diagnosis that interferes with permanent placement. ${ }^{99-102}$

Issues of genetic testing of children placed for adoption are even more complicated today, when many adoptions involve some degree of an open relationship with the child's birth parents. Testing results may have implications for the extended family members of the birth parents, and such issues should be discussed as part of the process. If the decision is to allow for preadoption testing, consideration of disclosure to the extended family of the birth parents must be addressed prospectively. Likewise, some children are adopted by biological relatives (e.g., grandparents, aunts, and uncles). Testing in these families may also have far-ranging implications that need to be addressed before testing is performed.

An adoption agency may decide that it will give preference to individuals or couples who are willing to accept an at-risk child without testing, although prospective parents will require extensive anticipatory guidance. One could argue, however, that a child facing a serious medical prognosis is best served by having a condition diagnosed early and being placed with a family equipped to deal with the challenges ahead. ${ }^{96-98}$

The adopted child or child born of donor gametes has a medical interest in knowing his or her family genetic history. ${ }^{103}$
Despite debate about whether such knowledge is in the child's overall best interest ${ }^{104}$ and whether the child's interest always trumps other familial interests, ${ }^{104-106}$ there is a persistent call for access to genetic parentage information on reaching adulthood, even if donors or relinquishing parents were promised anonymity. ${ }^{104,107-110}$ For discussion about the role of the physician in facilitating communication about these issues, see the AAP statement on the topic. ${ }^{111}$

\section{DISCLOSURE}

Parents or guardians occasionally request that genetic test results not be disclosed to a child. ${ }^{112,113}$ Similar requests are sometimes encountered in conditions such as HIV and cancer. ${ }^{114-118}$ With respect to HIV, the AAP supports disclosure on the grounds that it improves self-esteem, ensures that the child learns in a positive environment, and promotes the child's growing role in the health-care process. ${ }^{118,119}$ More generally, the AAP supports disclosure because children often sense that something is wrong, and nondisclosure may lead to feelings of abandonment. ${ }^{118}$

With respect to predictive genetic testing, a request for nondisclosure may indicate ambivalence on the part of the parent or guardian regarding the significance of the test results and, thus, a potential for harm either from the parent's interpretation or from the child's eventual discovery of the concealment. ${ }^{118}$ As the child matures, justifying such a request may become more difficult, even if the health-care provider agrees that disclosure might not promote the well-being of the child. The health-care provider should consider deferring testing if not clinically necessary, pending a detailed discussion of these issues. ${ }^{4}$

Ideally, health-care providers and parents or guardians should address disclosure issues before genetic testing. The adolescent candidate for testing ordinarily should be a participant in these discussions and should concur with the proposed plans. During pretest genetic counseling, parents should be made aware that the genetic information belongs to the child being tested and that they should be prepared to share the results with the child either at the time of testing or at a defined time in the future. ${ }^{4}$

If genetic testing occurs before the request for nondisclosure to the child, the health-care provider may wish to defer a decision about disclosure until after the issues have been explored fully. Factors such as the age of the child, the need for medical interventions, and the need for the child to participate in therapeutic plans must be considered. The AAP and the ACMG believe that a request for the results of a genetic test by a mature adolescent should be given priority over his or her parents' requests to conceal information. When a younger child is tested and the parents request that the provider not reveal results, the provider should engage the parents in an ongoing discussion about the benefits and harms of nondisclosure, the child's interest in the information, and when and in what manner the results will be disclosed. Ideally, a system or plan would be developed such that when the child reaches adulthood, the individual could be made aware of the existence of the test results and be given the option to know the results, but how to achieve this in 
a fragmented health-care system is unclear, underscoring the importance of a medical home for every child. ${ }^{120}$

As noted previously, genetic testing may produce evidence that the biological relationships among family members are different from the stated relationships. Pretest counseling should alert parents or guardians to this possibility, ${ }^{27,65}$ thus providing an opportunity to forgo testing or seek alternatives to the proposed test to avert undesired consequences. Even when parentage is not the issue, genetic testing of an individual may have implications for other family members. Whether physicians or patients have a legal duty to warn extended family members about known genetic risks is unsettled. It is well established that the physician's duty to preserve patient confidentiality may give way to a duty to report or take other action, including warning third parties, in the event of contagion or credible threats of serious violence. Genetic risk differs from infectious disease risk in its lack of temporal urgency, among other things. ${ }^{121-124}$ But the public policy interest in averting foreseeable harm has led some courts to find negligence on the parts of physicians who failed to make a timely genetic diagnosis or to alert family members about potential genetic risks.

When diagnosis of a childhood-onset genetic condition is negligently delayed, physicians may be held liable to the index patient for delayed therapeutic intervention ${ }^{125}$ and to parents for loss of reproductive options and the added costs of raising a subsequently born affected child. ${ }^{126-129}$

More recently, courts have been asked whether the diagnosis of a hereditary cancer syndrome in an adult creates duties to other family members. In parallel cases, the supreme courts of Florida and New Jersey held that the physician's duty to recognize and disclose the heritable nature and familial implications of a cancer syndrome must be measured by the standard of care at the time of the original physician-patient encounter. ${ }^{130,131}$ Both appellate courts allowed relatives to go forward at the trial level to establish whether an oncologist had a duty, in the early 1960s, to disclose the heritable nature of familial adenomatous polyposis (Safer v. Estate of Pack, New Jersey) or an otolaryngologist had a duty, in the early 1990s, to disclose the heritable nature of medullary thyroid carcinoma (Pate $v$. Threlkel, Florida). Although the Florida court declared that any such duty would be satisfied by informing the patient of risks to other family members, the New Jersey court declined to foreclose a potential duty to warn a relative over the objections of a patient. ${ }^{130,131}$

Previous commentators have supported a limited warning to relatives at risk of serious harm that could be avoided by prompt action, when attempts to persuade the patient to disclose have failed. ${ }^{121-124}$ Others argue that few, if any, genetic risks are so urgent as to justify breach of confidentiality. ${ }^{132}$ Most conclude that continuing dialog with the patient, including offers to assist in disclosure, is the preferable course; however, a disclosure to third parties that is limited to the information required to take action is permissible. ${ }^{133}$ Disclosure may be warranted if the consequences of a delayed diagnosis are severe, interventions are available and time is of the essence, a risk is not likely to be appreciated without disclosure, or misinformation has been conveyed in the past. ${ }^{134}$

\section{PATERNITY TESTING}

Historically, in the United States, a child born to a married woman was presumed by law to be the biological child of her husband. With the advent of surrogacy, donor gametes, and same-sex couples, the legal recognition of parentage has become more complex. Moreover, $40 \%$ of children in the United States are born to nonmarried parents. ${ }^{135}$ Typically, in the absence of marriage, paternity is legally established either by a written acknowledgment or by genetic testing. Genetic paternity testing may be performed to establish or challenge child support, custody, or visitation rulings. Although testing is best performed on a triad (mother-father-child), it is possible using samples from a dyad (father-child). Assays can be performed using blood, cheek swabs, or other tissue.

Misattributed paternity may be suspected, for example, when a person offers to be an organ donor for a close relative and an $\mathrm{ABO}$ or HLA mismatch is revealed. ${ }^{136,137}$ However, a finding suggestive of nonpaternity must be verified by formal testing. ${ }^{138}$ Mismatches at a single locus or chromosomal region are insufficient to establish nonparentage. Other possible explanations include sampling error, labeling error, interpretive error, new mutation, and uniparental disomy. The loci sampled during formal paternity testing are selected for the express purpose of providing a thorough and statistically reliable assessment of parentage. ${ }^{139,140}$

\section{DIRECT-TO-CONSUMER GENETIC TESTING}

Direct-to-consumer (DTC) companies currently offer a wide variety of genetic assays, including paternity testing, carrier testing, nutritional profiling, and multiplex panels claiming to assess risk of monogenic and complex multifactorial conditions. ${ }^{141}$ To avoid regulatory requirements, some are marketed not as medical assays but as "recreational" tests. Their sensitivity, specificity, accuracy, and interpretive reliability are difficult to assess. Although direct access to medical testing increases consumer autonomy and supports self-determination, it raises a number of questions.

In 2004, the ACMG issued a statement concluding that "due to the complexities of genetic testing and counseling, the selfordering of genetic tests by patients over the telephone or the Internet, and their use of genetic "home testing" kits, is potentially harmful. Potential harms include inappropriate test utilization, misinterpretation of test results, lack of necessary follow-up, and other adverse consequences." ${ }^{142}$

In 2010, the US General Accounting Office reported the results of its investigation on DTC testing to the Subcommittee on Oversight and Investigations, Committee on Energy and Commerce, House of Representatives. ${ }^{143}$ The investigation uncovered evidence of unfounded genetic predictions, misleading test results, deceptive marketing, and other questionable practices. ${ }^{143}$ 
The effects of DTC genetic testing on children have not been evaluated by any professional body. Only a few DTC companies specify that their websites are not directed to children; ${ }^{144}$ regardless, there is no practicable way to prevent minors from engaging in DTC testing without parental knowledge. A survey of social networkers in the United States found that 6\% of respondents had engaged in personal genome testing, and an additional $64 \%$ indicated an interest in doing so. Of these respondents, the majority were interested in carrier testing for someone other than themselves, including their progeny, even though less than half were confident that they understood the risks and benefits of personal genome testing. ${ }^{145}$

Tabor and Kelley ${ }^{146}$ suggest that DTC companies have a moral responsibility to educate parents about the risks of testing their children, to discourage testing of minors for rare genetic traits "particularly if they have no reason to be concerned about increased family risk," and to provide genetic counseling to avoid misunderstandings.

The AAP and the ACMG strongly discourage the use of DTC and home-kit genetic testing of children. In addition to the risks of inaccurate results, inaccurate interpretations, potentially harmful interventions, and altered family dynamics are possible negative consequences. ${ }^{85,147}$ DTC testing raises issues of privacy, self-determination, and disclosure vis-à-vis parents and children, as discussed previously in the section on Disclosure. Professional involvement is indicated in any type of genetic testing on minors.

\section{GENETIC SERVICES}

Genetic counselors and medical geneticists are too few in number to take primary responsibility for managing all genetic testing and counseling. ${ }^{148-150}$ Primary and subspecialty pediatric care providers must have a working knowledge of the genetic issues likely to affect their patient populations ${ }^{150-152}$ and either have sufficient expertise to prepare families adequately before ordering genetic testing ${ }^{65}$ or refer such testing to a genetics professional.

The primary care provider often will serve as care coordinator and medical home for children with genetic conditions. ${ }^{52,153-155}$ Resources such as the AAP newborn screening fact sheet ${ }^{156}$ and the ACMG newborn screening action plans, known as ACT sheets, ${ }^{157}$ can help primary care providers interpret and manage genetic diagnoses in collaboration with a child's metabolic or genetic specialist, hematologist, endocrinologist, neurologist, or infectious disease specialist. Greater familiarity with genetics is of special importance for physicians serving minority patients, who are less likely to be appropriately referred for genetic testing and counseling. ${ }^{158}$ The AAP and the ACMG support the expansion of educational opportunities in human genetics for medical students, residents, and practicing physicians and the expansion of training programs for genetics professionals. ${ }^{64}$

\section{ACKNOWLEDGMENTS}

This document is copyrighted and is property of the American Academy of Pediatrics and its board of directors. The American Academy of Pediatrics has neither solicited nor accepted any commercial involvement in the development of the content of this publication. The guidance in this report does not indicate an exclusive course of treatment or serve as a standard of medical care. Variations, taking into account individual circumstances, may be appropriate. All technical reports from the American Academy of Pediatrics automatically expire 5 years after publication unless reaffirmed, revised, or retired at or before that time.

American Academy of Pediatrics Committee on Bioethics, 2011-2012

Mary E. Fallat, MD, Chairperson

Aviva L. Katz, MD

Mark R. Mercurio, MD

Margaret R. Moon, MD

Alexander L. Okun, MD

Sally A. Webb, MD

Kathryn L. Weise, MD

Past Contributing Committee Members

Armand H. Matheny Antommaria, MD, PhD

Ian R. Holzman, MD

Lainie F. Ross, MD, PhD*

Liaisons

Douglas S. Diekema, MD, MPH—American Board of Pediatrics

Kevin W. Coughlin, MD-Canadian Paediatric Society

Steven J. Ralston, MD-American College of Obstetricians and Gynecologists

Consultant

Jessica W. Berg, JD, MPH

Staff

Alison Baker, MS

American Academy of Pediatrics Committee on Genetics, 2011-2012

Robert A. Saul, MD, Chairperson

Stephen R. Braddock, MD

Emily Chen, MD, PhD

Debra L. Freedenberg, MD

Marilyn C. Jones, MD

James M. Perrin, MD

Beth Anne Tarini, MD, MS

Past Contributing Committee Members

Howard M. Saal, MD*

Gregory M. Enns, MB, ChB

Jeffrey R. Gruen, MD

Liaisons

Katrina M. Dipple, MD, PhD—American College of Medical Genetics

Stuart K. Shapira, MD, PhD—Centers for Disease Control and Prevention

Sara M. Copeland, MD-Health Resources and Services Administration

Melissa A. Parisi, MD, PhD—Eunice Kennedy Shriver National Institute of Child Health and Human Development

W. Allen Hogge, MD—American College of Obstetricians and Gynecologists

Staff

Paul Spire, MPH 


\section{American College of Medical Genetics and Genomics Social, Ethical and Legal Issues Committee, 2011-2012}

Karen L. David, MD, MS, Chair (lead author for the committee)

Louis E. Bartoshesky, MD, MPH, Vice Chair

Rebecca R. Anderson, JD, MS (lead author for the committee)

Robert G. Best, PhD

Jodi D. Hoffman, MD

Masamichi Ito, PhD

Amy A. Lemke, MS, PhD

Mitzi L. Murray, MD

Richard R. Sharp, PhD

Vikas Bhambhani, MD

Board Liaison

Lynn D. Fleisher, PhD, JD

Past Contributing Committee Members

Alexander Asamoah, MD, PhD

Gary S. Gottesman, MD

Lainie F. Ross, MD, PhD

\section{DISCLOSURE}

All authors have filed conflict of interest statements with the American Academy of Pediatrics. Any conflicts have been resolved through a process approved by the board of directors. Masamichi Ito, a member of the SELI Committee, works for Athena Diagnostics, a company that performs genetic testing in minors.

\section{REFERENCES}

1. Watson JD, Crick FH. Molecular structure of nucleic acids; a structure for deoxyribose nucleic acid. Nature 1953;171:737-738.

2. Tjio JH, Levan A. The chromosome number of man. Hereditas 1956;42:1-6.

3. Noble I. Human genome finally complete. BBC News Online. 14 April 2003. http://news.bbc.co.uk/2/hi/science/nature/2940601.stm. Accessed 11 January 2013.

4. American Society of Human Genetics Board of Directors, American College of Medical Genetics Board of Directors. Points to consider: ethical, legal, and psychosocial implications of genetic testing in children and adolescents. Am J Hum Genet 1995;57:1233-1241.

5. American Academy of Pediatrics, Committee on Bioethics. Ethical issues with genetic testing in pediatrics. Pediatrics 2001;107(6):1451-1455. Reaffirmed October 2004.

6. American Academy of Pediatrics, Committee on Bioethics, Committee on Genetics; American College of Medical Genetics, Social, Ethical, and Legal Issues Committee. Ethical and policy issues in genetic testing and screening of children. Pediatrics 2013;131(3):620-622.

7. Listernick R. A 30-month-old boy with developmental regression and hepatosplenomegaly. Pediatr Ann 2003;32:500-503.

8. Li D, Liao C. Incidental discovery of nonpaternity during prenatal testing of genetic disease. Fetal Diagn Ther 2008;24:39-41.

9. Husain A, Loehle JA, Hein DW. Clinical pharmacogenetics in pediatric patients. Pharmacogenomics 2007:8:1403-1411.

10. Cheok MH, Pottier N, Kager L, Evans WE. Pharmacogenetics in acute lymphoblastic leukemia. Semin Hematol 2009;46:39-51.

11. Meeker ND, Yang JJ, Schiffman JD. Pharmacogenomics of pediatric acute lymphoblastic leukemia. Exp Opin Pharmacother 2010;11(10):1621-1632.

12. Anderson GM, Cook EH. Pharmacogenetics. Promise and potential in child and adolescent psychiatry. Child Adolesc Psychiatr Clin N Am 2000;9:23-42, viii.

13. Polanczyk G, Bigarella MP, Hutz MH, Rohde LA. Pharmacogenetic approach for a better drug treatment in children. Curr Pharm Des 2010;16: 2462-2473.

14. Kieling C, Genro JP, Hutz MH, Rohde LA. A current update on ADHD pharmacogenomics. Pharmacogenomics 2010;11:407-419.

15. Madadi P, Koren G. Pharmacogenetic insights into codeine analgesia: implications to pediatric codeine use. Pharmacogenomics 2008;9: 1267-1284.
16. Williams DG, Patel A, Howard RF. Pharmacogenetics of codeine metabolism in an urban population of children and its implications for analgesic reliability. $\mathrm{Br} \mathrm{J}$ Anaesth 2002:89:839-845.

17. Koren G, Cairns J, Chitayat D, Gaedigk A, Leeder SJ. Pharmacogenetics of morphine poisoning in a breastfed neonate of a codeine-prescribed mother. Lancet 2006;368:704

18. Koster ES, Raaijmakers JA, Koppelman GH, et al. Pharmacogenetics of antiinflammatory treatment in children with asthma: rationale and design of the PACMAN cohort. Pharmacogenomics 2009;10(8):1351-1361.

19. Corvol H, De Giacomo A, Eng C, et al.; Genetics of Asthma in Latino Americans (GALA) Study; Study of African-Americans, Asthma, Genes and Environments (SAGE) Investigators. Genetic ancestry modifies pharmacogenetic gene-gene interaction for asthma. Pharmacogenet Genomics 2009;19:489-496.

20. Hines RN, McCarver DG. Pharmacogenomics and the future of drug therapy. Pediatr Clin North Am 2006;53:591-619.

21. National Research Council, Committee for the Study of Inborn Errors of Metabolism. Genetic Screening: Programs, Principles and Research. National Academy of Sciences: Washington, DC, 1975.

22. Wilson JMG, Jungner G. Principles and Practice of Screening for Disease. Public Health Papers 34. World Health Organization: Geneva, Switzerland, 1968. http://whqlibdoc.who.int/php/WHO_PHP_34.pdf. Accessed 18 September 2012

23. UK National Screening Committee. Programme appraisal criteria: criteria for appraising the viability, effectiveness and appropriateness of a screening programme. http://www.screening.nhs.uk/criteria. Accessed 11 January 2013.

24. Andermann A, Blancquaert I, Beauchamp S, Déry V. Revisiting Wilson and Jungner in the genomic age: a review of screening criteria over the past 40 years. Bull World Health Organ 2008;86:317-319.

25. Pollitt RJ. Newborn blood spot screening: new opportunities, old problems. $J$ Inherit Metab Dis 2009;32:395-399.

26. Paul DB. Patient advocacy in newborn screening: continuities and discontinuities. Am J Med Genet C Semin Med Genet 2008;148C:8-14.

27. Institute of Medicine, Committee on Assessing Genetic Risks. Assessing Genetic Risks: Implications for Health and Social Policy. Andrews LL, Fullarton JE, Holtzman NA, Motulsky AG (eds). National Academy Press: Washington, DC, 1994

28. American College of Medical Genetics, Health Resources and Services Administration. Newborn Screening: Toward a Uniform Screening Panel and System. Health Resources and Services Administration: Rockville, MD, March 2006. ftp://ftp.hrsa.gov/mchb/genetics/screeningdraftforcomment.pdf. Accessed 11 January 2013.

29. Canadian Paediatric Society, Bioethics Committee; Canadian College of Medical Geneticists, Ethics and Public Policy Committee. Guidelines for genetic testing of healthy children. Paediatr Child Health 2003;8(1):42-45. Reaffirmed February 2010.

30. Clarke A. The genetic testing of children. Working Party of the Clinical Genetics Society (UK). J Med Genet 1994;31:785-797.

31. British Society for Human Genetics. Report on the Genetic Testing of Children Birmingham, UK: British Society for Human Genetics, 2010. http://www. ethox.org.uk/Documents\%20and\%20images/GTOC_2010_BSHG.pdf. Accessed 11 January 2013.

32. US Congress, Office of Technology Assessment. Appendix I: data and methods used in OTA's cost-effectiveness analysis of strategies for newborn screening. In: Healthy Children: Investing in the Future. US Government Printing Office: Washington, DC, 1988:236-241. Publication No. OTA-H-345. http://www.fas. org/ota/reports/8819.pdf. Accessed 11 January 2013.

33. Holtzman NA, Watson MS. Task Force on Genetic Screening. Promoting Safe and Effective Genetic Testing in the United States. Final Report of the Task Force on Genetic Testing. Johns Hopkins University Press: Baltimore, MD, 1988.

34. President's Council on Bioethics. The Changing Moral Focus of Newborn Screening. Government Printing Office: Washington, DC, 2008.

35. Tarini BA, Christakis DA, Welch HG. State newborn screening in the tandem mass spectrometry era: more tests, more false-positive results. Pediatrics 2006;118:448-456.

36. Lipstein EA, Perrin JM, Waisbren SE, Prosser LA. Impact of false-positive newborn metabolic screening results on early health care utilization. Genet Med 2009:11:716-721.

37. Tluczek A, Orland KM, Cavanagh L. Psychosocial consequences of false-positive newborn screens for cystic fibrosis. Qual Health Res 2011:21:174-186.

38. Gurian EA, Kinnamon DD, Henry JJ, Waisbren SE. Expanded newborn screening for biochemical disorders: the effect of a false-positive result. Pediatrics 2006;117:1915-1921. 
39. Waisbren SE, Albers S, Amato S, et al. Effect of expanded newborn screening for biochemical genetic disorders on child outcomes and parental stress. JAMA 2003;290:2564-2572.

40. Grob R. The Transformation of Newborn Screening, Parenting, and Policymaking. Rutgers University Press: Newark, NJ, 2011.

41. DeLuca JM, Kearney MH, Norton SA, Arnold GL. Parents' experiences of expanded newborn screening evaluations. Pediatrics 2011;128:53-61.

42. Timmermans S, Buchbinder M. Patients-in-waiting: Living between sickness and health in the genomics era. J Health Soc Behav 2010;51:408-423.

43. Natowicz M. Newborn screening — setting evidence-based policy for protection. N Engl J Med 2005;353(9):867-870.

44. Botkin JR, Clayton EW, Fost NC, et al. Newborn screening technology: proceed with caution. Pediatrics 2006;117:1793-1799.

45. Calonge N, Green NS, Rinaldo P, et al.; Advisory Committee on Heritable Disorders in Newborns and Children. Committee report: Method for evaluating conditions nominated for population-based screening of newborns and children. Genet Med 2010;12:153-159.

46. Geleske TA. Recommendation made to add SCID to uniform newborn screening panel. AAP News 2010;31(6):22.

47. Lloyd-Puryear MA, Tonniges T, van Dyck PC, et al. American Academy of Pediatrics Newborn Screening Task Force recommendations: how far have we come? Pediatrics 2006;117(5 Pt 2):S194-S211.

48. Campbell E, Ross LF. Parental attitudes regarding newborn screening of PKU and DMD. Am J Med Genet A 2003;120A:209-214.

49. Davis TC, Humiston SG, Arnold CL, et al. Recommendations for effective newborn screening communication: results of focus groups with parents, providers, and experts. Pediatrics 2006;117(5 Pt 2):S326-S340.

50. Tluczek A, Orland KM, Nick SW, Brown RL. Newborn screening: an appeal for improved parent education. J Perinat Neonatal Nurs 2009;23:326-334.

51. Campbell ED, Ross LF. Incorporating newborn screening into prenatal care. Am J Obstet Gynecol 2004;190:876-877.

52. American Academy of Pediatrics, Newborn Screening Authoring Committee. Newborn screening expands: recommendations for pediatricians and medical homes -implications for the system. Pediatrics 2008;121(1):192-217.

53. American College of Obstetricians and Gynecologists, Committee on Genetics. Committee opinion no. 481: newborn screening. Obstet Gynecol 2011;117(3):762-765.

54. American Academy of Pediatrics, Newborn Screening Task Force. Serving the family from birth to the medical home. Newborn screening: a blueprint for the future-a call for a national agenda on state newborn screening programs. Pediatrics 2000;106(2):389-422.

55. Goldstein J, Freud A, Solnit A. Before the Best Interests of the Child, vol II. The Free Press: New York, NY, 1979.

56. Buchanan A, Brock D. Deciding for Others: The Ethics of Surrogate Decision Making. Cambridge University Press: New York, NY, 1989.

57. Ross LF. Children, Families, and Health Care Decision-making. Oxford University Press: Oxford, UK, 1998

58. Newson A. Should parental refusals of newborn screening be respected? Camb Q Healthc Ethics 2006;15:135-146.

59. Clayton EW. Screening and treatment of newborns. Houst Law Rev 1992:29:85-148.

60. Faden R, Chwalow AJ, Holtzman NA, Horn SD. A survey to evaluate parental consent as public policy for neonatal screening. Am J Public Health $1982 ; 72: 1347-1352$.

61. Wilcken B. Expanded newborn screening: reducing harm, assessing benefit. J Inherit Metab Dis 2010;33(suppl 2):S205-\$210.

62. Pollitt RJ. New technologies extend the scope of newborn blood-spot screening, but old problems remain unresolved. Acta Paediatr 2010;99:1766-1772.

63. Grosse SD, Boyle CA, Kenneson A, Khoury MJ, Wilfond BS. From public health emergency to public health service: the implications of evolving criteria for newborn screening panels. Pediatrics 2006;117:923-929.

64. Kemper AR, Trotter TL, Lloyd-Puryear MA, Kyler P, Feero WG, Howell RR. A blueprint for maternal and child health primary care physician education in medical genetics and genomic medicine: recommendations of the United States secretary for health and human services advisory committee on heritable disorders in newborns and children. Genet Med 2010;12:77-80.

65. American Academy of Pediatrics, Committee on Genetics. Molecular genetic testing in pediatric practice: a subject review. Pediatrics 2000;106(6):14041407

66. Wailoo K. Dying in the City of the Blues: Sickle Cell Anemia and the Politics of Race and Health. University of North Carolina Press: Chapel Hill, NC, 2001
67. Wailoo K, Pemberton S. The Troubled Dream of Genetic Medicine. Johns Hopkins University Press: Baltimore, MD, 2006.

68. Wade $\mathrm{CH}$, Wilfond BS, McBride CM. Effects of genetic risk information on children's psychosocial wellbeing: a systematic review of the literature. Genet Med 2010;12:317-326.

69. Tsaras G, Owusu-Ansah A, Boateng FO, Amoateng-Adjepong Y. Complications associated with sickle cell trait: a brief narrative review. Am J Med 2009;122:507-512

70. Jordan LB, Smith-Whitley K, Treadwell MJ, Telfair J, Grant AM, Ohene-Frempong K. Screening U.S. college athletes for their sickle cell disease carrier status. Am J Prev Med 2011;41(6 suppl 4):S406-S412.

71. Letter from Rodney Howell, Chairperson Secretary's Advisory Committee on Heritable Disorders in Newborns and Children, to The Honorable Kathleen Sebelius, Secretary of Health and Human Services, 14 June 2010, regarding the National Collegiate Athletic Association policy. http://www.hrsa.gov/ advisorycommittees/mchbadvisory/heritabledisorders/recommendations/ correspondence/sicklecell061410.pdf. Accessed 11 January 2013.

72. Politano L, Nigro V, Nigro G, et al. Development of cardiomyopathy in female carriers of Duchenne and Becker muscular dystrophies. JAMA 1996:275:13351338

73. Hagerman PJ, Hagerman RJ. The fragile-X premutation: a maturing perspective. Am J Hum Genet 2004;74:805-816.

74. Ross LF. Heterozygote carrier testing in high schools abroad: what are the lessons for the U.S.? J Law Med Ethics 2006;34:753-764.

75. Ross LF. Predictive genetic testing for conditions that present in childhood. Kennedy Inst Ethics J 2002;12:225-244.

76. Borry P, Stultiens L, Nys H, Cassiman JJ, Dierickx K. Presymptomatic and predictive genetic testing in minors: a systematic review of guidelines and position papers. Clin Genet 2006;70:374-381.

77. Rew L, Mackert M, Bonevac $D$. A systematic review of literature about the genetic testing of adolescents. J Spec Pediatr Nurs 2009;14:284-294.

78. Bancroft EK. Genetic testing for cancer predisposition and implications for nursing practice: narrative review. J Adv Nurs 2010;66:710-737.

79. Creighton S, Almqvist EW, MacGregor D, et al. Predictive, pre-natal and diagnostic genetic testing for Huntington's disease: the experience in Canada from 1987 to 2000. Clin Genet 2003;63:462-475.

80. Tassicker RJ, Teltscher B, Trembath MK, et al. Problems assessing uptake of Huntington disease predictive testing and a proposed solution. Eur J Hum Genet 2009;17:66-70

81. Barnoy S. Genetic testing for late-onset diseases: effect of disease controllability, test predictivity, and gender on the decision to take the test. Genet Test 2007;11:187-192.

82. Meiser B, Dunn S. Psychological impact of genetic testing for Huntington's disease: an update of the literature. J Neurol Neurosurg Psychiatr 2000;69:574578.

83. Kopelman LM. Using the Best Interests Standard to decide whether to test children for untreatable, late-onset genetic diseases. J Med Philos 2007:32:375-394.

84. Arribas-Ayllon M, Sarangi S, Clarke A. The micropolitics of responsibility vis-à-vis autonomy: parental accounts of childhood genetic testing and (non)disclosure. Sociol Health IIIn 2008;30:255-271.

85. Tercyak KP, Hensley Alford S, Emmons KM, Lipkus IM, Wilfond BS, McBride CM Parents' attitudes toward pediatric genetic testing for common disease risk. Pediatrics 2011;127:e1288-e1295.

86. Christensen KD, Jayaratne TE, Roberts JS, Kardia SL, Petty EM. Understandings of basic genetics in the United States: results from a national survey of black and white men and women. Public Health Genomics 2010;13:467-476.

87. American Academy of Pediatrics, Committee on Bioethics. Informed consent, parental permission and assent in pediatric practice. Pediatrics 1995;95(2):314317. Reaffirmed October 2006.

88. Hallowell N, Ardern-Jones A, Eeles R, et al. Men's decision-making about predictive BRCA1/2 testing: the role of family. J Genet Couns 2005;14:207-217.

89. Baumann SL. Family Systems genetic Illness Model-breast cancer. Clin J Oncol Nurs 2006;10:377-381.

90. Peterson SK. The role of the family in genetic testing: theoretical perspectives, current knowledge, and future directions. Health Educ Behav 2005:32: 627-639.

91. Van Riper M. Genetic testing and the family. J Midwifery Womens Health 2005;50:227-233.

92. Berlan ED, Bravender T. Confidentiality, consent, and caring for the adolescent patient. Curr Opin Pediatr 2009;21:450-456

93. Tillett J. Adolescents and informed consent: ethical and legal issues. J Perinat Neonatal Nurs 2005;19:112-121. 
94. American Academy of Pediatrics, Committee on Bioethics. Policy statement: children as hematopoietic stem cell donors. Pediatrics 2010;125(2):392-404.

95. Ross LF, Thistlethwaite JR Jr; Committee on Bioethics. Minors as living solidorgan donors. Pediatrics 2008;122:454-461.

96. American Society of Human Genetics, Social Issues Committee; American College of Medical Genetics, Social, Ethical, and Legal Issues Committee. Genetic testing in adoption. Am J Hum Genet 2000;66(3):761-767.

97. Jansen LA, Ross LF. The ethics of preadoption genetic testing. Am J Med Genet 2001;104:214-220.

98. Wheeler R. Predictive testing for pre-malignancy as a prelude to adoption? An English case. Fam Cancer 2010;9:71-74.

99. Newson AJ, Leonard SJ. Childhood genetic testing for familial cancer: should adoption make a difference? Fam Cancer 2010;9:37-42.

100. Wisconsin Clinical Genetics Center and Waisman Center on Mental Retardation and Human Development. Disclosing genetic information to adoptive parents: ethical considerations. In: Fost N (ed). Genetic Family History: An Aid to Better Health of Adoptive Children. National Center for Education in Maternal and Child Health: Washington, DC, 1984;50-55.

101. Andrews LB, Elster N. Adoption, reproductive technologies, and genetic information. Health Matrix Clevel 1998;8:125-151.

102. Freundlich MD. The case against preadoption genetic testing. Child Welfare 1998;77:663-679.

103. Hill CM, Wheeler R, Merredew F, Lucassen A. Family history and adoption in the UK: conflicts of interest in medical disclosure. Arch Dis Child 2010;95:7-11.

104. Sauer JL. Competing interests and gamete donation: the case for anonymity. Seton Hall Law Rev 2009;39:919-954.

105. Greene C. Donor conception and children's rights: a parent's decision. CMAJ 2011;183:400.

106. Burr J, Reynolds P. Thinking ethically about genetic inheritance: liberal rights, communitarianism and the right to privacy for parents of donor insemination children. J Med Ethics 2008;34:281-284

107. Johnson L, Kane H. Regulation of donor conception and the "time to tell" campaign. J Law Med 2007;15:117-127.

108. Lalos A, Gottlieb C, Lalos O. Legislated right for donor-insemination children to know their genetic origin: a study of parental thinking. Hum Reprod 2007;22:1759-1768.

109. Frith L, Blyth E, Farrand A. UK gamete donors' reflections on the removal of anonymity: implications for recruitment. Hum Reprod 2007;22:16751680.

110. Daniels K. Donor gametes: anonymous or identified? Best Pract Res Clin Obstet Gynaecol 2007;21:113-128.

111. Borchers D; American Academy of Pediatrics Committee on Early Childhood, Adoption, and Dependent Care. Families and adoption: the pediatrician's role in supporting communication. Pediatrics 2003;112(6 Pt 1):1437-1441.

112. Clarke A, Richards M, Kerzin-Storrar L, et al. Genetic professionals' reports of nondisclosure of genetic risk information within families. Eur J Hum Genet 2005; 13:556-562.

113. Sigman GS, Kraut J, La Puma J. Disclosure of a diagnosis to children and adolescents when parents object. A clinical ethics analysis. Am J Dis Child 1993; 147:764-768.

114. Bluebond-Langner M. The Private Worlds of Dying Children. Princeton University Press: Princeton, NJ, 1980.

115. Claflin CJ, Barbarin OA. Does "telling" less protect more? Relationships among age, information disclosure, and what children with cancer see and feel. $J$ Pediatr Psychol 1991;16:169-191.

116. Leikin SL. An ethical issue in pediatric cancer care: nondisclosure of a fatal prognosis. Pediatr Ann 1981;10(10):37-41, 44-45.

117. Gerson AC, Joyner M, Fosarelli P, et al. Disclosure of HIV diagnosis to children: when, where, why, and how. J Pediatr Health Care 2001;15:161-167.

118. Levetown M; American Academy of Pediatrics Committee on Bioethics. Communicating with children and families: from everyday interactions to skill in conveying distressing information. Pediatrics 2008;121:e1441-e1460.

119. American Academy of Pediatrics, Committee on Pediatric AIDS. Disclosure of illness status to children and adolescents with HIV infection. Pediatrics 1999;103(1):164-166.

120. American Academy of Pediatrics, Ad Hoc Task Force on Definition of the Medical Home. The medical home. Pediatrics 1992;90:774.

121. The American Society of Human Genetics, Social Issues Subcommittee on Familial Disclosure. Professional disclosure of familial genetic information. Am J Hum Genet 1998;62(2):474-483.

122. American Society of Clinical Oncology. Policy statement update: genetic testing for cancer susceptibility. Clin Oncol 2003;21(12):2397-2406.
123. President's Commission for the Study of Ethical Problems in Medicine and Biomedical and Behavioral Research. Screening and Counseling for Genetic Conditions: A Report on the Ethical, Social, and Legal Implications of Genetic Screening, Counseling, and Educational Programs. US Government Printing Office: Washington, DC, 1983. http://bioethics.georgetown.edu/pcbe/reports/ past_commissions/geneticscreening.pdf. Accessed 18 September 2012.

124. American Medical Association, Code of Medical Ethics. Opinion E-2.131: Disclosure of Familial Risk in Genetic Testing. http://www.ama-assn.org/ama/ pub/physician-resources/medical-ethics/code-medical-ethics/opinion2131. page. Accessed 11 January 2013.

125. Bunting v Jamieson, 984 P.2d 467 (Wyo 1999).

126. Molloy v Meier, 679 N.W.2d 711, 714 (Minn 2004)

127. Schroeder v Perkel, 87 NJ 53, 423 A.2d 8834 (NJ 1981).

128. Lininger v Eisenbaum, 764 P.2d 1202 (Colo 1988)

129. Clark v Children's Memorial Hospital, No. 108656, Supreme Court of Illinois, September 2011.

130. Pate v Threlkel, 661 So 2 d 278 (Fla 1995).

131. Safer v Estate of Pack, 677 A2d 1188 (NJ App), appeal denied, 683 A2d 1163 (NJ 1996)

132. Clayton EW. What should the law say about disclosure of genetic information to relatives? J Health Care Law Policy 1998:1:373-390.

133. Health Insurance Portability and Accountability Act. 45 CFR 164.512(j).

134. Anderson R, Haidle JL. Legal considerations in clinical cancer genetics. Commun Oncol 2006;3(2):100-104.

135. Benson C. Can crossnational theories of nonmarital childbearing explain nonmarital childbearing patterns observed across U.S. states? Working Paper/ PCS, 10 November 2009. http://www.ssc.wisc.edu/soc/pcs/Presentations/ Nonmarital\%20Childbearing\%20US_Crossnational\%20Models_110709.doc. Accessed 11 January 2013.

136. Wright L, MacRae S, Gordon D, et al. Disclosure of misattributed paternity: issues involved in the discovery of unsought information. Semin Dial 2002;15:202-206

137. Soderdahl DW, Rabah D, McCune T, et al. Misattributed paternity in a living related donor: to disclose or not to disclose? Urology 2004;64:590.

138. Ross LF. Good ethics requires good science: why transplant programs should not disclose misattributed parentage. Am J Transplant 2010;10:742-746.

139. Wegener R, Weirich V, Dauber EM, Mayr WR. Mother-child exclusion due to paternal uniparental disomy 6. Int J Legal Med 2006;120:282-285.

140. Walker RH, Pohl BA. Paternity testing with an absent mother. The probability of exclusion of red cell surface antigen, Gm, Hp, and HLA systems in North American whites and blacks. Transfusion 1989;29:31-35.

141. Hudson K, Javitt G, Burke W, Byers P; American Society of Human Genetics Social Issues Committee. ASHG Statement* on direct-to-consumer genetic testing in the United States. Obstet Gyneco/ 2007;110:1392-1395.

142. American College of Medicine Genetics Board of Directors. ACMG statement on direct-to-consumer genetic testing. Genet Med 2004;6(1):60.

143. General Accounting Office. Statement of Gregory Kutz, Managing Director Forensic Audits and Special Investigations as Testimony Before the Subcommittee on Oversight and Investigations, Committee on Energy and Commerce, House of Representatives. Direct-to-Consumer Genetic Tests: Misleading Test Results Are Further Complicated by Deceptive Marketing and Other Questionable Practices. General Accounting Office: Washington, DC, 22 July 2010.

144. Borry P, Howard HC, Sénécal K, Avard D. Health-related direct-to-consumer genetic testing: a review of companies' policies with regard to genetic testing in minors. Fam Cancer 2010;9:51-59.

145. McGuire AL, Diaz CM, Wang T, Hilsenbeck SG. Social networkers' attitudes toward direct-to-consumer personal genome testing. Am J Bioeth 2009:9:3-10

146. Tabor HK, Kelley M. Challenges in the use of direct-to-consumer personal genome testing in children. Am J Bioeth 2009:9:32-34.

147. Sanderson SC, Wardle J. Associations between anticipated reactions to genetic test results and interest in genetic testing: will self-selection reduce the potential for harm? Genet Test 2008;12:59-66.

148. Holtzman NA. Primary care physicians as providers of frontline genetic services. Fetal Diagn Ther 1993;8(suppl 1):213-219.

149. Carroll JC, Rideout AL, Wilson BJ, et al. Genetic education for primary care providers: improving attitudes, knowledge, and confidence. Can Fam Physician 2009;55:e92-e99.

150. Dumont-Driscoll M. Genetics and the general pediatrician: where do we belong in this exploding field of medicine? Curr Probl Pediatr Adolesc Health Care 2002;32:6-28. 
151. Lose EJ. The emerging role of primary care in genetics. Curr Opin Pediatr 2008:20:634-638.

152. Rosas-Blum E, Shirsat $P$, Leiner M. Communicating genetic information: a difficult challenge for future pediatricians. BMC Med Educ 2007; 7:17.

153. Kemper AR, Uren RL, Moseley KL, Clark SJ. Primary care physicians' attitudes regarding follow-up care for children with positive newborn screening results. Pediatrics 2006;118:1836-1841.

154. Oyeku SO, Feldman HA, Ryan K, Muret-Wagstaff S, Neufeld EJ. Primary care clinicians' knowledge and confidence about newborn screening for sickle cell disease: randomized assessment of educational strategies. J Natl Med Assoc 2010;102:676-682.
155. Wells AS, Northrup H, Crandell SS, et al. Expanded newborn screening in Texas: a survey and educational module addressing the knowledge of pediatric residents. Genet Med 2009:11:163-168.

156. Kaye Cl, Accurso F, La Franchi S, et al.; Committee on Genetics. Newborn screening fact sheets. Pediatrics 2006;118:e934-e963.

157. American College of Medical Genetics. ACMG ACT SHEETS and Confirmatory Algorithms. http://www.acmg.net/AM/Template.cfm?Section=ACT_Sheets_and Confirmatory_Algorithms\&Template=/CM/HTMLDisplay. cfm\&ContentID=5661 . Accessed 11 January 2013

158. Shields AE, Burke W, Levy DE. Differential use of available genetic tests among primary care physicians in the United States: results of a national survey. Genet Med 2008; 10:404-414. 